\title{
Anti-inflammatory and antipyretic activity of Fioria vitifolia
}

\author{
Krishnamoorthi Mahalakshmi ${ }^{1}$ *Senthil Kumar Natesan², Kugalur ganesan Parthiban², Ganesan Sekar ${ }^{2}$ \\ ${ }^{1}$ Prist University, Tanjore, Tamil Nadu, India \\ ${ }^{2} J$ KKMMRF College of pharmacy, Komarapalayam, Namakkal, Tamil Nadu, India
}

\begin{abstract}
Fioria vitifolia Linn., (Malvacae) has been extensively used in folk medicine for the treatment of common cold, flu, and upper respiratory infections and also as an immune system booster. Steroids, flavonoids, and triterpenes, gossypin alkaloids have been isolated from the whole part of the plant. In the present study, the methanolic extract of dried plant of Fioria vitifolia (MEFV) was investigated for anti-inflammatory (carrageenan induced rat paw oedema) and anti-pyretic (brewer's yeast induced pyrexia) activities. Pre-treatment with the extract $(250-500 \mathrm{mg} / \mathrm{kg}$, p. o) significantly prevented increase in volume of paw oedema in dose dependent manner. A maximal effect was observed at $500 \mathrm{mg} / \mathrm{kg}$ which was comparable to diclofenac (20mg/kg, orally). Ceiling effect at the dose of $500 \mathrm{mg} / \mathrm{kg}$ was observed. The anti-pyretic effect of MEFV (measured as \% reduction in body temperature) was compared with paracetamol $(150 \mathrm{mg} / \mathrm{kg}$, orally). MEFV in dose of $500 \mathrm{mg} / \mathrm{kg}$ caused significant decrease in body temperature of rat s. In conclusion, this study has established the anti-inflammatory activity and anti pyretic activity of Fioria vitifolia and thus, justifies the ethnicuses of the plant.
\end{abstract}

Key Words: Carrageenan, Malvacae, rat paw oedema, diclofenac, ethnicuses, Fioria vitifolia.

\section{INTRODUCTION}

Fioria vitifolia Linn, commonly known as Hibiscus vitifolius, belongs to the family of Malvacae grows widely in tropical and sub-tropical regions. It is frequently used in folk medicine too. Fioria vitifolia roots extract shows potent protective action against anti-tubercular drug induced hepato toxicity. Some phytoconstituents like sterols, flavonoids, and triterpenes, alkaloids have been isolated from the plant However, no data was found regarding the pharmacological and phytochemical evaluation of the plant. The aim of the present study is to investigate the anti-inflammatory and antipyretic properties of the methanolic extracts of dried plant of Fioria vitifolia. (The wealth of India, 2005)

\section{MATERIALS AND METHODS}

The plant of Fioria vitifolia Linn. was collected from Kallankattu valasu near Komarapalayam, Tamilnadu, India. The plant was authenticated and identified at Botanical survey of India, Coimbatore Tamilnadu, India.

\section{Acute oral toxicity study}

- The method uses defined doses (5, 50, 300, $2000 \mathrm{mg} / \mathrm{kg}$ body weight) and the results allow a substance to be ranked and classified according to the Globally Harmonized system (GHS) for the classification of chemical which cause acute toxicity. Most of the crude extracts possess LD50 value more than $2000 \mathrm{mg} / \mathrm{kg}$ of the body weight of animal used (Amroyan et al., 1997).

- Dose volume was administered $0.1 \mathrm{ml} / 100$ gm body weight to the animal by oral route. After giving the dose, the toxic signs should be observed within 3-4 hours.

\footnotetext{
*Corresponding Author:

Dr. Senthil Kumar Natesan, Principal

JKK Munirajah Medical research foundation

College of pharmacy, Komarapalayam

Namakkal Dt. South India

E-mail: senthilkumarjkkm@gmail.com

Contact No.: +919789456737
}

- No toxicity or death was observed for these given dose levels, in selected and treated animals. So the LD50 of the ethanol extract of Fioria vitifolia Imbach, fruiting bodies as per OECD guidelines-423 is greater than $2000 \mathrm{mg} / \mathrm{kg}$ (LD50 > 2000mg/kg).

\section{Drugs and reagents}

Diclofenac (MicroLab, India), Carrageenan (SigmaAldrich), Brewer's yeast (Loba Chem, Mumbai) and Paracetamol (GlaxoSmithKline) were AR grade used in the study.

\section{Preparation of extracts}

The plant was washed thoroughly, dried under a shade and pulverized. The coarse powder was extracted with methanol using a soxhlet apparatus to obtain Fioria vitifolia methanolic extract (MEFV). The extracts were dried using a rotary vacuum evaporator and stored in a desiccators until further use (Cooper and Gunn, 1960).

\section{Animals}

Wistar albino rats of both sexes, weighing 150-200g were used for the study. The animals were kept in polypropylene cages in a room maintained under controlled atmospheric conditions. The animals were fed with standard diet (Hindustan liver, Mumbai, India) and had free access to clean drinking water. The experimental protocol was approved by the Institutional Animal Ethical Committee (IAEC/008/2012/CPCSEA) of JKKMMRF College of Pharmacy, Komarapalayam. Namakkal Dt. Tamilnadu.

\section{Anti-inflammatory activity}

The anti-inflammatory activity of the extract was determined, using carrageenan induced rat paw oedema assay (Winter et al., 1962). The rats were divided into five groups of six rats each. The control group received $1 \%$ $(\mathrm{v} / \mathrm{v})$ DMSO in water at a dose of $5 \mathrm{ml} / \mathrm{kg}$. The positive control group was treated orally with the standard drug, diclofenac $(20 \mathrm{mg} / \mathrm{kg})$. The test groups received the MEFV in doses of $250,500 \mathrm{mg} / \mathrm{kg}$. All the doses were ad- 
Table 1: Effect of Fioria vitifolia on paw oedema induced by carrageenan in rats.

\begin{tabular}{|c|c|c|c|}
\hline \multirow{2}{*}{ Drug dose } & \multicolumn{3}{|c|}{ Paw volume (ml) } \\
\hline & 1hr & $2 \mathrm{hrs}$ & $3 \mathrm{hrs}$ \\
\hline Control & $18.00 \pm 1.00$ & $21.33 \pm 2.00$ & $22.00 \pm 3.05$ \\
\hline $\begin{array}{l}\text { Standard (indomethacin- } \\
20 \mathrm{mg} / \mathrm{kg} \text { ) }\end{array}$ & $9.33 \pm 0.33^{c}$ & $7.00 \pm 0.57^{c}$ & $6.66 \pm 0.88^{b}$ \\
\hline MEFV $(500 \mathrm{mg} / \mathrm{kg})$ & $15.00 \pm 1.00$ & $7.66 \pm 0.66^{c}$ & $7.16 \pm 0.48^{b}$ \\
\hline MEFV $(250 \mathrm{mg} / \mathrm{kg})$ & $18.66 \pm 0.88$ & $14.00 \pm 0.63^{\mathrm{b}}$ & $13.33 \pm 1.17^{\mathrm{a}}$ \\
\hline
\end{tabular}

ministered 30min before the induction of oedema by administering $0.1 \mathrm{ml}$ of $1 \% \mathrm{w} / \mathrm{v}$ carrageenan in saline in sub plantar region of hind paw of animal. The degree of paw oedema of the entire group was measured using a plethysmo meter at 60,120 and $180 \mathrm{~min}$ after the administration of carrageenan to each group (Adams et al., 1968).

\section{Antipyretic activity}

Antipyretic activity was measured by Brewer's induced pyrexia in rats. Male Wistar rats were fasted over night with water adlibitum before the experiments. Pyrexia was induced by subcutaneously injecting $20 \% \mathrm{w} / \mathrm{v}$ brewer's yeast suspension $(10 \mathrm{ml} / \mathrm{kg})$ into the animal's dorsum region. Twelve hours after the injection, the rectal temperature of each rat was measured using a digital tele thermometer only, rats that showed an increase in temperature of at least $0.7^{\circ} \mathrm{C}$ were used for the experiments. MEFV in doses of 250, $500 \mathrm{mg} / \mathrm{kg}$ was administered orally and the temperature was measured at $1,2,3$ \& 4 hrs after drug administration. Paracetamol $(150 \mathrm{mg} / \mathrm{kg})$ was used as standard drug (Hayare et al., 2000).

\section{Statistical treatment}

The results were subjected to two way ANOVA followed by dunnet's test. The data is deemed to be statistically significant if $\mathrm{p}<0.05$.

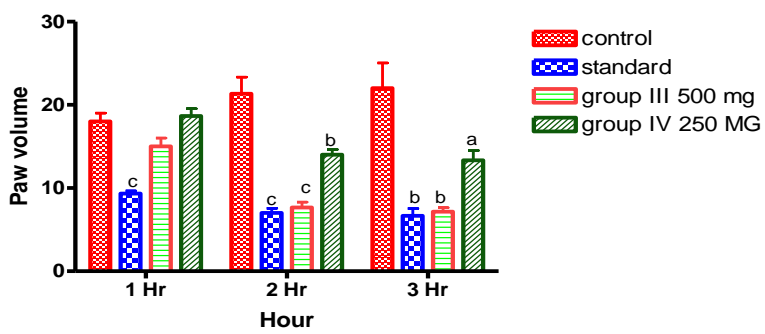

Figure 1: Effect of Fioria vitifolia on paw oedema induced by carrageenan in rats.

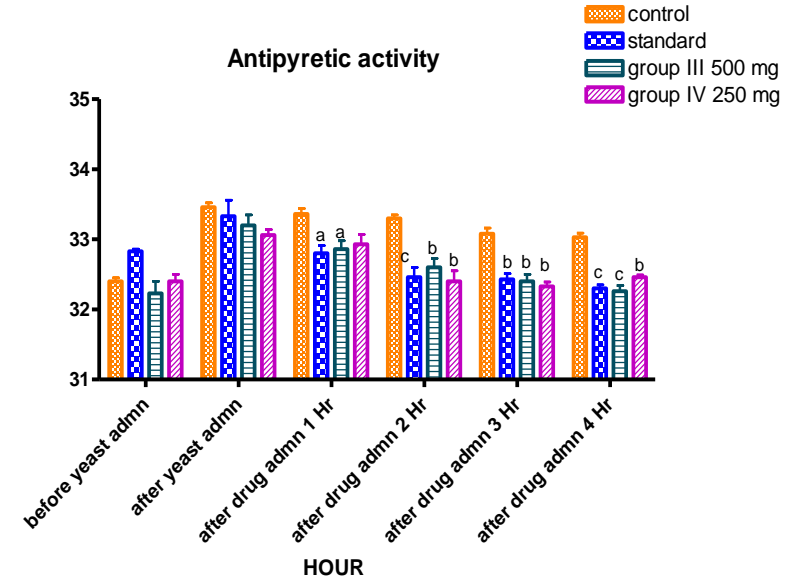

Figure 2: Effect of Fioria vitifolia on yeast induced pyrexia in rats.

\section{RESULTS}

The methanolic extract of Fioria vitifolia significantly decreased the paw oedema induced by carrageenan in rats at the dose of $500 \mathrm{mg} / \mathrm{kg}$ comparable to indomethacin $(20 \mathrm{mg} / \mathrm{kg}$ ) (Table 1). Effect of the Fioria vitifolia on brewer's yeast-induced pyrexia in rats was significant and showed reduction in rectal temperature of rats (Table 2). Preliminary phytochemical screening revealed the presence of alkaloids, flavonoids, tannins, sterols, triterpenoids and carbohydrates in the methanolic extract of the whole plant of Fioria vitifolia.

\section{DISCUSSION}

Carrageenan induced paw oedema is a commonly used primary test for the screening of new anti- inflammatory agents and it is believed to be biphasic. The first phase (1$2 \mathrm{hr}$.) is due to the release of histamine or serotonin and the second phase of oedema is due to the release of prostaglandin. The results of this study indicate that the methanolic extract of Fioria vitifolia significantly reduced carrageenan induced paw oedema in rats. Therefore, the mechanism of action may be by inhibition of histamine, serotonin or prostaglandin synthesis. Usually most antiinflammatory and analgesic drugs possess antipyretic activity. In general, non-steroidal anti- inflammatory drugs produce their anti-pyretic action through the inhibition of prostaglandin synthetase within the hypothalamus. Therefore, the antipyretic activity of methanolic extract of Fioria vitifolia is probably by inhibition of prostaglandin synthesis in hypothalamus. The anti- inflammatory and antipyretic activities of methanolic extract may be due to the presence of alkaloids, sterols and flavonoids, triterpenoids.

Table 2: Effect of Fioria vitifolia on yeast induced pyrexia in rats.

\begin{tabular}{ccccccc}
\hline \multirow{2}{*}{ Drug dose } & Before yeast & After yeast & \multicolumn{4}{c}{ After Drug Administration } \\
\cline { 4 - 7 } & administration & administration & $\mathbf{1 h r}$ & $\mathbf{2 h r}$ & $\mathbf{3 h r}$ & $\mathbf{4 h r}$ \\
Control & $32.40 \pm 0.05$ & $33.46 \pm 0.06$ & $33.36 \pm 0.88$ & $33.30 \pm 0.05$ & $33.08 \pm 0.08$ & $33.03 \pm 0.06$ \\
Standard & $32.83 \pm 0.03$ & $33.33 \pm 0.23$ & $32.80 \pm 0.11^{\mathrm{a}}$ & $32.46 \pm 0.14^{\mathrm{c}}$ & $32.43 \pm 0.08^{\mathrm{b}}$ & $32.30 \pm 0.05^{\mathrm{c}}$ \\
MEFV 500 mg & $32.23 \pm 0.17$ & $33.20 \pm 0.15$ & $32.86 \pm 0.12^{\mathrm{a}}$ & $32.60 \pm 0.13^{\mathrm{b}}$ & $32.40 \pm 0.10^{\mathrm{b}}$ & $32.26 \pm 0.08^{\mathrm{c}}$ \\
MEFV 250 mg & $32.40 \pm 0.10$ & $33.06 \pm 0.08$ & $32.93 \pm 0.14$ & $32.50 \pm 0.15^{\mathrm{b}}$ & $32.33 \pm 0.06^{\mathrm{b}}$ & $32.46 \pm 0.03^{\mathrm{b}}$ \\
\hline
\end{tabular}

Values are given as mean \pm S.E.M for groups of six animals each. Values are statistically significant at ${ }^{*} p<0.05 .\left({ }^{a}=p<0.05 ;{ }^{b}=p<0.01 ;{ }^{c}=p<0.001\right)$

All group values and significance were compared with control group 


\section{CONCLUSION}

The results show that the plant Fioria vitifolia has significant anti-inflammatory and antipyretic activities. However, further investigation is required to isolate the active constituents responsible for these activities and to elucidate the exact mechanisms of action.

\section{ACKNOWLEDGEMENT}

The authors are very much thankful to Dr. J.K.K Munirajah, M. Tech (Bolton) D. Litt Chairman, J.K.K. Munirajah Educational Institutions, B. Komarapalayam, Tamilnadu, for providing necessary facilities for carrying out this research work.

\section{REFERENCES}

Adams, S.S., Hebborn, P., Nicholson, J.S. (1968). Some aspects of the pharmacology of ibufenac, a non-steroidal anti- inflammatory agent. Journal of Pharmacy and Pharmacology, Volume 20, Pages 305-312. [DOI

Amroyan, E. Caballero, EE, sanchez, N.S., et al. (1997). Testicular toxicity assessment of dried extract in rats. Journal of Ethnopharmacology ,Volume 58, Pages 219-224. [DOI]

Cooper, J. W. and Gunn, Colin (1960). Tutorial Pharmacy, Pitman Medical Publishing Co.

Hayare-SW, Chandra, S, Tandon, S.K, Sarma, J. Lal, J., Telang, A. G. (2000), Analgesic and anti Pyretic activities of dalbergia sissoo leaves Indian journal of pharmacology, volume 32, pages 357-360.

Rawlines E. A. ELBS (1979). Text Book of Pharmaceutics, Bailliere Tindale East bourn Cast, Sussex, UK

Shroff, M. L. (1975) General Pharmacy, Five Star Publiations, Kolkatta The wealth of India, (2005), Volume 3, D-1, Page 289.

Winter, C.A., Risley, E.A., Nuss, G.W. (1962). Carrageenin-induced oedema in hind paws of the rat as an assay for anti- inflammatory drugs Procedure. Scholarly Experimental Biological Medicine, volume 111 , pages $544-547$. 